AL-FANAR

Jurnal Ilmu Al-Quran dan Tafsir
Volume 4, Nomor 2, 2021, hlm. 157-166

P-ISSN: 2622-2280 | E-ISSN: 2622-4658

https://ejurnal.iiq.ac.id/index.php/alfanar

\title{
Kewaspadaan terhadap Keluarga dan Harta dalam QS. Al-Taghabun [54]: 14-15
}

(Aplikasi Pendekatan Ma'nā-cum-Maghzā)

\author{
M. Marovida Aziz \\ UIN Sunan Kalijaga Yogyakarta \\ vidaaziz20@gmail.com
}

DOI: $10.33511 /$ alfanar.v4n2.157-166

Submitted: 2021-06-14, Revised: 2021-07-09, Accepted: 2021-08-18

\begin{abstract}
This article examines and analyzes the attitude that must be taken when family and property become enemies, obstacles and trials. To understand it, that family and property are inseparable, humans are born to have a family, while to meet the daily needs of a family requires property as a basic need such as clothing and food. This paper will explain that in having a family and managing wealth there are more or less trials and tests in it, so in the sura QS. al-Taghabun [64]: 1415-explains vigilance towards family and property. By using the Ma>nā-cum-Maghzā approach formulated by Sahiron Syamsuddin, the author wants to see the meaning of the main message behind being vigilance of our family and property, by analyzing the language of the verse and looking at the historical context of the verse. With this step, it leads to a concrete conclusion that when dealing with wives and children who hinder us, we should not use violence, and when we get sustenance in the form of wealth we must be able to manage it well and in the right way.
\end{abstract}

Keywords: Family, Treasure, Vigilance, Ma'nā-cum-Maghzā.

\section{Abstrak}

Artikel ini mengkaji dan menganalisis sikap yang harus dilakukan ketika keluarga dan harta menjadi musuh, penghalang dan cobaan. Untuk memahaminya, bahwa keluarga dan harta merupakan suatu hal yang tak terpisahkan, manusia terlahir pasti mempunyai keluarga, sedangkan untuk memenuhi kebutuhan sehari-hari dalam berkeluarga membutuhkan harta sebagai kebutuhan pokok seperti sandang dan pangan. Tulisan ini akan menjelaskan bahwa dalam berkeluarga dan mengelola harta sedikit banyaknya terdapat cobaan dan ujian di dalamnya, maka dalam surah Q.S AtTaghabun (64): 14-15 menjelaskan kewaspadaan terhadap keluarga dan harta. Dengan menggunakan pendekatan Ma'nā-cum-Maghzā yang dirumuskan oleh Sahiron Syamsuddin, penulis ingin melihat makna pesan utama dibalik kewaspadaan terhadap keluarga dan harta yang kita miliki, dengan mengalisis bahasa ayat serta melihat konteks historis ayat. Dengan langkah tersebut, mengantar pada konklusi konkrit bahwa ketika menyikapi istri dan anak yang mengahalangi kita, sepatutnya tidak menggunakan kekerasan, serta ketika mendapat rizki berupa harta harus bisa mengelola dengan baik dan di jalan yang benar.

Kata Kunci: Keluarga, Harta, Kewaspadaan, Ma'nā-cum-Maghzāa. 
Kewaspadaan terhadap Keluarga dan Harta dalam QS. Al-Taghabun [54]: 14-15 (Aplikasi Pendekatan Ma'nā-cum-Maghzā)

\section{PENDAHULUAN}

Kewaspadaan sebagai pemimpin keluarga tidak hanya pada permasalahan yang ada diluar (eksternal) saja, terkadang permasalahan itu muncul di dalam (internal) keluarga tersebut. Data dari catatan Komnas perempuan, ${ }^{1}$ terdapat kasus kekerasan pada perempuan (KTP) sepanjang tahun 2020 terdapat kasus 299.911 baik itu yang berbasis gender atau tidak. Berbagai masalah yang muncul dalam keluarga tersebut bisa karena faktor perselingkuhan, masalah ekonomi, budaya patriarki, maupun adanya pihak ketiga. Permasalahan keluarga juga bisa muncul disebabkan oleh faktor upaya pengelolan harta yang tidak benar. Mempunyai harta banyak tidak menjamin keluarga tersebut bisa harmonis, harta yang melimpah bisa melalaikan dan juga bisa menjadi cobaan. Jika seseorang tidak mengerti hakikat dan fungsi harta, termasuk cara mendapatkan dan cara memanfaatkannya, besar kemungkinan ia bisa terjerumus dalam kehinaan baik di dunia dan akhirat. Ambil contoh adalah kisah Qorun yang sudah masyhur yaitu manusia yang gagal memahami hakikat dan fungsi dari harta, dia menjadi hamba dari harta, isi otaknya hanya harta dan harta, tidak peduli dari mana mendapatkannya dan penggunaanya. ${ }^{2}$ Cobaan yang lain juga kadang muncul dari anak, karena apabila salah mendidik anak juga bisa menyebabkan tercoreng nama baik orang tua, baik itu dalam permasalahan dunia dan akhirat.

Kehidupan dalam berkeluarga, pasti tidak terlepas dengan adanya permasalahan dalam keluarga, seperti halnya ketika seorang istri membangkang terhadap suami maka terdapat istiliah Nusyuz yaitu ketika istri tidak menaati perintah dan menentang/ membangkang. ${ }^{3}$

Sejauh ini studi tentang keluarga dan harta, hanya menyinggung atas hak hak kewajiban menafkahi keluarga. ${ }^{4}$ Serta juga QS. at-Taghabun ayat 14-15 dilihat dari segi nilai-nilai pendidikan akhlak dalam berkeluarga. ${ }^{5}$ Dari kecenderungan tersebut, masih belum ada studi penelitian yang menjelaskan kandungan bahaya kewaspadaan dan pesan utama yang harus diambil dari QS al-Taghabun ayat 14-15.

Dengan menggunakan metode interpretasi Ma'nā-cum-Maghzā langkah metode konkrit yaitu dengan menganalisa bahasa teks Al-Qur'an, dengan memperhatikan Al-Qur'an turun pada abad ke 7 Masehi yang karekteristik tersendiri. Selanjutnya memahami konteks ayat itu turun (situasi dan kondisi) baik itu mikro atau makro. Setelah itu penulis mencoba menggali Maqshod atau pesan utama yang sedang ditafsirkan, hal ini dapat dilakukan dengan mengamati secara cermat konteks historis dan ekspresi kebahasan Al-Qur'an. Dengan mengombinasikan antara makna, yakni makna awal

1 https://komnasperempuan.go.id/siaran-pers-detail/catahu-2020-komnas-perempuan-lembarfakta-dan-poin-kunci-5-maret-2021.

${ }^{2}$ Usin Artyasa, Ternyata balasan memberikan pinjaman lebih besar daripada sedekah, (Bandung: ruang kata, 2013), h. 40.

${ }^{3}$ Adil Fathi, Ketika suami istri hidup bermasalah, Terj. Abd Hayyie, (Jakarta: Gema insani, 2005), h. 141.

${ }^{4}$ Jumni Nelli, "Analisis tentang kewajiban nafkah keluarga dalam pemberlakuan harta bersama”, Jurnal Al-Istinbath: Jurnal Hukum Islam, Vol. 2, No. 1 (2017). http://journal.iaincurup.ac.id/index. php/alistinbath/article/view/195.

${ }^{5}$ Erika Wijayanti Arifah, "Konsep Pendidikan Keluarga dalam Al-Qur'an Surat Al-Taghabun Ayat 14-16” (Skripsi-Sarjana IAIN Salatiga, 2018).

158 | Al-Fanar: Jurnal Ilmu Al-Qur'an dan Tafsir 
dari sebuah ayat dan Maghza yaitu signifikansi atau pesan utama sebuah ayat. maka penelitian ini diharpakan mampu menjelaskan adanya kewaspadaan terhadap keluarga dan harta dalam QS. al-Taghabun 14-15.

\section{SEKILAS PENDEKATAN $M A^{\prime} N \bar{A}-C U M-M A G H Z \bar{A}$ SAHIRON SYAMSUDDIN}

Sahiron Syamsuddin adalah seorang sarjana dalam studi Al-Qur'an di UIN Sunan Kalijaga Yogyakarta, beliau telah mengenalkan teori Ma'nā-cum-Maghzāa, teori ini menjelaskan bahwa seorang pembaca harus mencari makna awal teks (makna objektif) yang dipahami oleh penerima atau pendengar pertama Al-Qur'an, selanjutnya dari makna awal itu dicari signifikansinya terhadap konteks hari ini (modern). Teori Ma'nā-cum-Maghzā mengasumsikan bahwa setiap kata (simbol) dalam sebuah teks apapun termasuk Al-Qur'an memiliki makna historis yang spesifik dalam konteks tertentu. ${ }^{6}$

Teori Ma'nā-cum-Maghzā dalam metodologisnya adalah dengan menganalisa bahasa teks Al-Qur'an abad ke 7 M. yang mempunyai karakternya sendiri, baik kosa katanya maupun struktur tata bahasanya, dengan langkah analisa intratekstualitas (membandingkan dan menganalisa dengan ayat yang lain) dan intertekstualitas (membandingkan dan menganalisa ayat dengan teks-teks lain yang ada di sekitar AlQur'an. Penafsir memperhatikan konteks historis pewahyuan ayat Al-Qur'an baik yang mikro atau makro, itu semua bisa menjelaskan tekait latar belakang turunnya suatu ayat. Selanjutnya penafsir mencoba menggali maghza (tujuan/pesan utama ayat) hal ini bisa diketahui dengan memperhatikan secara cermat konteks historis dan ekspresi kebahasaan Al-Qur'an. ${ }^{7}$

\section{APLIKASI $M A A^{\prime} N \bar{A}-C U M-M A G H Z \bar{A}$ QS. AL-TAGHABUN [64]: 14-15}

\section{QS. Al-Taghabun [64]: 14-15}

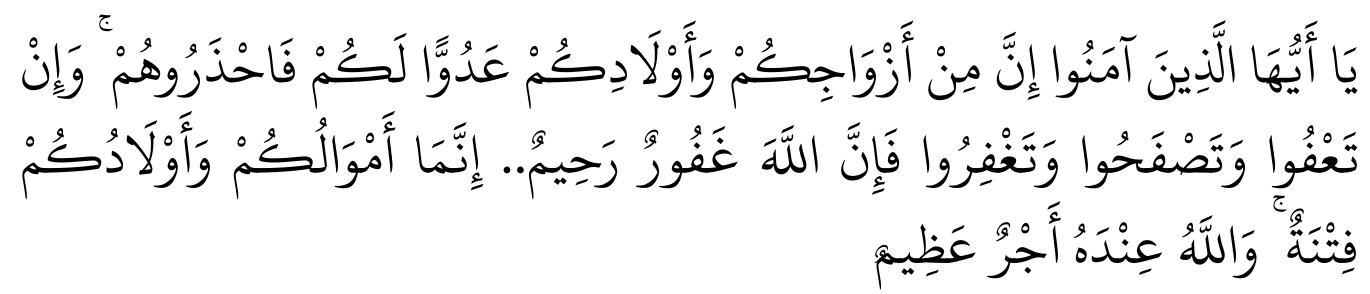

Hai orang-orang mukmin, sesungguhnya di antara isteri-isterimu dan anakanakmu ada yang menjadi musuh bagimu maka berhati-hatilah kamu terhadap mereka dan jika kamu memaafkan dan santuni serta mengampuni (mereka) maka sesungguhnya Allah Maha Pengampun lagi Maha Penyayang. Sesungguhnya hartamu dan anak-anakmu hanyalah cobaan (bagimu), dan di sisi Allah-lah pahala yang besar. (QS. Al-Taghabun [64]: 14-15)

${ }^{6}$ Adi Fadilah, "Ma'na-Cum-Maghza sebagai Pendekatan Kontekstual dalam Perkembangan Wacana Hermenutika Al-Qur'an di Indonesia”, Jurnal Of Qur'an and Hadith studies, Vol. 8, No. 1, (2019), h. 12. http://journal.uinjkt.ac.id/index.php/journal-of-quran-and-hadith/article/ download/13383.

7 Sahiron Syamsuddin, Hermeneutika dan Pengembangan Ulumul Qur'an, (Yogyakarta: pesantren nawesea press, 2017), h. 141. 
Kewaspadaan terhadap Keluarga dan Harta dalam QS. Al-Taghabun [54]: 14-15

(Aplikasi Pendekatan Ma'nā-cum-Maghzā)

\section{Analisisi Linguistik atas QS Al-Taghabun [64]: 14-15}

Untuk menganalisi linguistik atau bahasa teks Al-Qur'an, baik kosakata maupun strukturnya, Menurut Sahiron Syamsuddin harus memperhatikan bahwa bahasa yang digunakan adalah bahasa arab abad ke-7 M. oleh karena itu maka seyogyanya dalam pencarian dengan menggunakan kamus bahasa arab klasik, yaitu dengan menggunakan kamus Lisān al-Arab karya Ibnu Manzur, sebab dalam kamus tersebut berhasil merekam dan menjelaskan makna kata-kata pada masa diturunkannya AlQur'an.

Yā ayyuhā al-ladzina āmanū inna min azwājikum wa aulādikum 'aduwwan lakum fa ihdzarūhum

Makna yang harus digali adalah kata 'aduwwan. Dalam kamus Lisān al-Arab kata aduwwan adalah bentuk masdar dari fiil madhi 'Ad $\bar{a}$, kata ini mempunyai dua makna, makna yang pertama adalah 'berlari', makna kedua adalah 'meninggalkan/ memalingkan'. Masdarnya bisa 'adwun dan 'aduwwun bermakna lawan dari teman, bentuk pluralnya adalah $a^{\prime} d \bar{a}$ ' (musuh). ${ }^{8}$ Kata ihdzarūhum (kata perintah plural dari kata ihdzar) dalam kamus Lisān al-'Arab bermakna kharajū hadzalīl ikhtadzirū lā yalqakum 'berhati-hatilah kalian ketika menaiki kuda karena bisa menjatuhkan, maka kata ihdzar menunjukan arti perintah untuk berhati-hati atau waspada. ${ }^{9}$

Pada pangkal ayat diterangkan dengan memakai huruf min yang berarti "daripada, artinya setengah dari pada, tegasnya bukanlah semua istri atau anak-anak menjadi musuh, akan tetapi hanya kadang-kadang atau pernah ada. Hasil dari sikap mereka telah merupakan suatu musuh yang menghambat cita-cita seorang mukmin sebagai ayah atau sebagai ayah. Sebagai contoh istri yang jadi musuh suami akan ditemukan pada QS. alTahrim [66]: 10, contoh perumpamaan anak adalah, pada kisah Nabi Nuh, ketika salah satu putranya tidak mau ikut beliau menaiki bahtera yang telah disediakan, sehingga putra tersebut akhirnya tenggelam.

Wa in ta'fū wa taşfậu wa taghfirū fa inna alllaha ghafūr al-raḥìm

Kata ta'fü, tasfaḥu, dan taghfirū menurut kamus Lisān al-'Arab bahwasanya kesumuanya memiliki arti yang sama yaitu memaafkan atau mengampuni, sedangkan pada kata selanjutnya yaitu menggunakan kata ghafür (sifat Allah) yang berbentuk mubalaghah (makna sangat). ${ }^{10}$

\section{Innamā amwālakum wa awlādukum fitnah wa allahu 'indahū ajrun 'adzīm}

Kata fitnah merupakan bentuk masdar dari fatana yang dalam kamus Lisān al'Arab mempunyai arti cobaan, ujian. Sedangkan al-fitnah mempunyai arti al-khibrah (mengetahui dengan percobaan/diuji). ${ }^{11}$ Penjelasan pada ayat Innamā amwālakum wa awlādukum fitnah, kata fitnah dalam kamus Lisān al- 'Arab terdapat dua macam/bentuk cobaan, cobaan itu bisa terasa manis dan juga bisa terasa pahit, karena cobaan tersebut semuanya sudah dipastikan akan meninggalkanya ketika hari akhir. ${ }^{12}$

\footnotetext{
${ }^{8}$ Ibn Manzur, Lisān al-Arab (Bairut: Dar al-Kutub al-Alamiyyah, 2008), Juz 19, h. 257

${ }^{9}$ Ibn Manzur, Lisān al-Arab, Juz 5, h. 248.

${ }^{10}$ Ibn Manzur, Lisān al-Arab, Juz 6, h. 329.

${ }^{11}$ Ibn Manzur, Lisān al-Arab, Juz 17, h. 193.

${ }^{12}$ Ibn Manzur, Lisān al-Arab, Juz 17, h. 197.
}

160 | Al-Fanar: Jurnal Ilmu Al-Qur'an dan Tafsir 


\section{Konteks Historis}

Mengenai konteks historis dalam mengkaji sebuah ayat, upaya yang dilakukan adalah dengan cara mengupayakan menyebutkan konteks mikro dan konteks makronya. Adapun mengenai konteks mikro, penulis menemukan riwayat yang menjelaskan sebab turunya ayat ini. Dalam Tafsir Ibnu Katsir, Ibnu Hatim meriwayatkan dari Ibnu Abbas, dan dia pernah ditanyai tentang ayat ini "Hai orang-orang beriman, sesungguhnya di antara isteri-isterimu dan anak-anakmu ada yang menjadi musuh bagimu maka berhati-hatilah kamu terhadap mereka" Dia mengatakan, mereka adalah merupakan orang-orang yang telah menyatakan diri mereka masuk Islam dari kota Makkah, kemudian mereka hendak bertemu dengan dengan Rasulullah SAW., namun ketika itu istri-istri dan anak-anak mereka menolak untuk ikut, akan tetapi akhirnya ikut hijrah ke madinah dan bertemu dengan Rasulullah SAW, kemudian mereka bermaksud memberikan hukuman kepada istri dan anak mereka, maka Allah menurunkan ayat selanjutnya yaitu: "jika kamu memaafkan dan santuni serta mengampuni (mereka) maka sesungguhnya Allah Maha Pengampun lagi Maha Penyayang." Demikianlah yang diriwayatkan oleh Imam At-Tirmidzi dan Muhammad bin Yahya, dari al-Firyani, hadis ini merupakan Hadis Hasan Shahih. ${ }^{13}$

Dalam riwayat lain, Hadis diriwayatkan Ibnu Jarir dari Atha' ibn Yasar, dijelaskan bahwa seluruh surah At-Taghabun diturunkan di Makkah, kecuali pada ayat 14 ini yang turun di Madinah, Ayat ini turun berkenaan dengan Sahabat yang bernama Auf ibn Malik Al-Asyja'i yang mempunyai keluarga anak dan istri, yang mana selalu menangisinya apabila akan berangkat berperang bahkan menghalanginya dengan berkata: "kepada siapa engkau akan titipkan kami ini”. Ia merasa kasian kepada anak dan istrinya dan tidak jadi berangkat berperang. Sehingga turunlah ayat ini. ${ }^{14}$

Teks Al-Qur'an yang telah 14 abad yang lalu, seharusnya perlu dipahami sesuai dengan konteks ketika Al-Qur'an itu turun (Asbāb al-Nuzūl). Maka disini penulis mencoba mencari sebab umum atau Asbāb al-Nuzūl makro. Teks-teks Al-Qur'an yang berkaitan dengan perang harus dibaca dengan menggunakan bacaan kontekstual. Perang yang terjadi pada era sebelum Nabi datang dan perang sesudah ada Nabi dan juga era sesudah Nabi wafat, pasti mempunyai perbedaan terkait aturan berperang. Sehingga pemahaman teks perang era Nabi di mana pada saat itu negara masih bersifat primitif, akan mempunyai pemaknaan berbeda dengan pemaknaan perang pasca negara bangsa. Perubahan konteks negara bangsa tentunya pasti beriringan dengan konsep negara yang sudah lintas suku, lintas bangsa.

Dalam sejarah, bahwasanya peperangan pada zaman Nabi, kebanyakan pasukan yang ikut dalam peperangan adalah para sahabat laki-laki yang mampu berperang, dan fisiknya kuat. Terkait peran wanita atau seorang istri pada zaman Nabi ketika keadaan perang, pada dasarnya perempuan tidak diwajibkan ikut dalam mengikuti peperangan karena tidak adanya keahlian dalam bidang berperang dan menghadapi musuh. Namun ada beberapa perempuan yang ikut dalam medan peperangan yang bertugas membuat makanan, mengobati para pasukan muslim yang terluka, dan merawat pasukan perang yang masih terluka. Keikutsertaan para perempuan dalam peperangan itu atas izin Nabi

${ }^{13}$ Ibnu Kathīr, Tafsīr Ibnu Kathīr, terj. Abdul Ghofar Dkk (Bogor: pustaka imam al-syafi'i, 2004), Juz. 28, h. 203.

14 Jalāl al-Dīn al-Suyūti, Lubāb al-Nuqūl fi Asbāb al-Nuzūl, (Bairut: Mu'sasah al-kitab alsaqafiyah, 2002), h. 267. 
untuk mendampingi mahrom untuk menjadi bantuan bagi para mujahidin, diantara perempuan yang ikut perang, yaitu ketika perang uhud adalah Ummu Umarah, Hamna binti Jahsy, Ummu aiman dan lain-lain. ${ }^{15}$

Peran wanita sebagai seorang istri dari suami yang ikut berperang yang sepatutnya selalu men-support dan tidak berupaya untuk menghalangi atau melarang dalam keikutsertaan suami dalam perang, penjelasan seperti ini ada riwayat yang mengisahkan "ada seorang perempuan mendatangi Rasulullah dan berkata: wahai Rasalullah, saya adalah perwakilan dari para istri datang untuk menanyakan perihal jihad seorang perempuan, jihad diwajibkan bagi kaum laki-laki, apabila mereka terluka mendapat pahala yang besar, dan apabila gugur, maka sungguh mereka tetap hidup disisi Tuhannya, dan kami para wanita ingin melaksanakan jihad seperti itu, maka Rasulullah menjawab: sampaikanlah perkataanku kepada mereka, bahwa sesungguhnya taat kepada suami dan mengakui hak-haknya itu dapat menyamai pahala jihadnya suami, dan sedikit dari kalian mengerjakannya". ${ }^{16}$

Dikisahkan juga dalam kisah Sahabat Umar bin Khatab, mengenai seorang suami berapa lama dia bisa meninggalkan keluarganya ketika sedang dalam keadaan jihad ikut dalam berperang, dikisahkan Abu Hafsh meriwayatkan dari Zaid bin Aslam, suatu malam ketika Umar bin Khatab sedang ronda, beliau lewat di depan rumah seseorang, yang mana terdengar di dalamnya ada seorang perempuan sedang bersair "malam ini terasa panjang, sunyi senyap hitam kelam, telah lama aku tiada kekasih yang kucumbu dan kurayu". Sehingga Umar menanyakan hal tersebut kepada seseorang yang tidak sengaja berpapasan, seseorang tersebut menjelaskan bahwa suami dari fulanah (perempuan) tersebut sedang ikut perang di jalan Allah. Oleh karena itu Umar mengunjungi putrinya (Khafsah), wahai putriku, sebarapa lama sabarnya seorang perempuan ketika ditinggal suaminya? Khafsah heran dan mengucapkan tasbih, seorang ayah bertanya hal seperti ini kepada putrinya, Umar menjawab: kalau bukan dalam kepentingan umat, pasti tidak akan menanyakan hal terkait ini, Khafsah menjawab, istri bisa bersabar ketika ditinggal suaminya kira-kira lima bulan enam bulan. Oleh karena itu Umar memerintahkan kepada komandan perang untuk sejak saat itu, memerintahkan seseorang boleh perang tidak lebih dari enam bulan lamanya. ${ }^{17}$

Beberapa informasi terkait kondisi sosial masyarakat Islam awal pada era peperangan, penulis ingin menunjukan bahwa peran seorang istri dari suami yang ikut dalam perang di jalan Allah, adalah sepatutnya selalu mendukung dan men-support suami, dan jangan menghalangi atau melarang untuk ikut melaksanakan perang, sebab peran istri yang selalu mendukung dan taat kepada suami juga termasuk dalam andil jihad bagi seorang istri.

\section{Pendapat Mufassir Klasik dan Kontemporer}

Menurut al-Tabari ayat ini bahwasanya ditakwil dengan "sesungguhnya di antara istri-istrimu dan anak-anakmu ada yang menjadi musuh bagimu", maksudnya adalah kita harus bisa menuntut/memandu kejalan Allah, karena di antara istri-istrimu dan

${ }^{15}$ Muhammad Gilang Ansori, "Peranan Wanita Sahabat Rasulullah SAW dalam Perang Uhud Tahun 3H/625M”, (Skripsi fakultas Adab dan Humaniora UIN sunan ampel, 2018), h 16.

${ }^{16} \mathrm{Abu}$ bakar ahamd bin umar al-Bazzar, Musnad al-Bazzār, (Madinah: maktabah al-'Ulūm wa al-Hukm, 2009), Juz 11, h. 377.

${ }^{17}$ Abd al-'Azīz al-ḥalāwī, Fatāwī wa Aqdiyati Amīr al-Mu'minīn 'Umar ibn al-Khatb, (Kairo: Maktabah Al-Qur'an), h. 131-132.

162 | Al-Fanar: Jurnal Ilmu Al-Qur'an dan Tafsir 
anak-anakmu bisa saja menghalangi untuk taat kepada Allah. "maka berhati-hatilah kamu terhadap mereka", dengan cara dengan mendekati apa yang diperintahkan oleh mereka yang mana perintah atau keinginan mereka bisa menjauhkan atau sampai meninggalkan ketaatan terhadap Allah. ${ }^{18}$ Ayat selanjutnya bahwasanya "sesungguhnya hartamu dan anak-anakmu hanyalah merupakan fitnah", yaitu adalah merupakan bala' (cobaan) bagimu di dunia. ${ }^{19}$

Menurut Buya Hamka, ayat ini tidak sepenuhnya seorang istri dan anak menjadi musuh, namun tetapi hanya terkadang istri dan anak-anak bisa saja menjadi musuh, sekurang-kurangnya menjadi musuh-musuh yang menghambat cita-cita. Diceritakan ada seorang sahabat yang ingin ikut masuk Islam dan hijrah ke Madinah, setelah maksud dan keinginannya diutarakan kepada istri dan anak-anak mereka, namun istri dan anak tersebut enggan ikut hijarh ke madinah, besar kemungkinan mereka merasa berat meninggalkan harta benda yang ada di Makkah dan juga tidak tahan menderita jika hijrah ke Madinah. Orang-orang yang telah menyatakan beriman itu kagum bisa mendengar teman-temannya yang hijrah itu telah banyak mengetahui tentang hal agama, sedang mereka sudah jauh ketinggalan. Tetapi oleh karena ada istri dan anak-anak yang tidak suka, maka ada di antara mereka yang hendak menghukum istri-istri dan anakanak mereka. Ayat ini menjelaskan terkait peringatan bahwa kadang-kadang istri-istri dan anak-anak di antara meraka ada yang manjadi musuh, yaitu musuh penghalang citacita, maka sebab itu disuruhlah orang-orang yang beriman untuk senantiasa berhati-hati terhadap mereka jangan sampai mereka itu mempengaruhi keyakinan, namun jangan langsung mengambil sikap keras terhadap mereka, bimbinglah mereka dengan baik dan santun. ${ }^{20}$

Ayat selanjutnya juga dijelaskan oleh Buya Hamka bahwa harta dan anak-anak yang dimiliki itu dapat menjadi fitnah artinya menjadi percobaan bagi keteguhan iman, karena bagaimanpun juga setiap orang pasti bangga jika mempunyai harta banyak dan juga anak-anaknya jadi orang yang bisa memenuhi apa yang diharapkan, tetapi karena keduanya antara harta dan anak-anak itu merupakan perhiasan dunia saja bisa jadi sebuah fitnah atau cobaan di dunia. Yang mana sesuai dengan ayat yang lain pada QS. al-Kahfi: 46. "Harta dan anak-anak adalah perhiasan kehidupan dunia tetapi amalanamalan yang kekal lagi saleh adalah lebih baik pahalanya di sisi Tuhanmu serta lebih baik untuk menjadi harapan". ${ }^{21}$

Imam Ahmad bin Hanbal meriwayatkan sebauh Hadis, berita dari Abu Buraidah, bahwa pada suatu hari Nabi Muhammad SAW sedang berkhutbah, tiba-tiba datanglah kedua cucu Nabi, yaitu Hasan dan Husain yang ketika itu masih kecil, yang keduanya memakai baju gamis merah, berjalan berlari dan jatuh dengan gembiranya, sehingga keduanya sampai ke hadapan mimbar Nabi, lalu kemuidan Nabi turun dari mimbar, lalu keduanya dipangku dan beliau teruskan Khutbahnya:

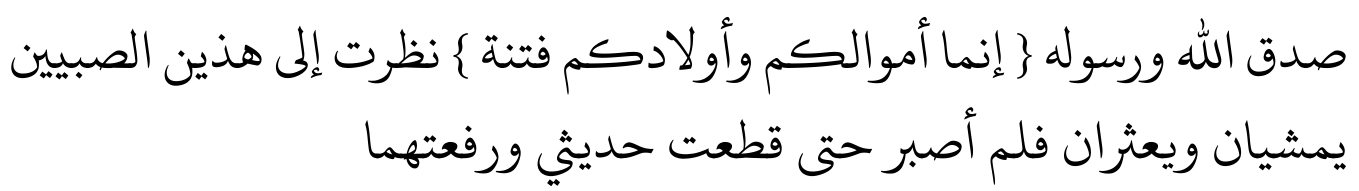

${ }^{18}$ Al-Tabari, Jāmi' al-Bayān fì ta'wīl Al-Qur'ān, (Bairut: Muasasah al-risalah, 2000), Juz 23, h. 423.

\footnotetext{
${ }^{19}$ Al-Tabari, Jāmi' al-Bayān fì ta'wīl Al-Qur'ān, Juz 23, h. 426.

${ }^{20}$ Hamka, Tafsir al-Azhar, (Singapura: pustaka nasional), juz 10, h. 7444.

${ }^{21}$ Hamka, Tafsir al-Azhar, Juz 10, h. 7446.
} 
Kewaspadaan terhadap Keluarga dan Harta dalam QS. Al-Taghabun [54]: 14-15

(Aplikasi Pendekatan Ma'nā-cum-Maghzā)

Benar Allah dan RasulNya bahwa hartabenda dan anak-anak kamu adalah fitnah (cobaan), aku lihat kedua anak ini berjalan tertatih-tatih, maka akupun tidak bersabar lagi, aku hentikan pembicaraanku dan aku pangku keduanya. ${ }^{22}$

Begitu halusnya didikan yang dijelaskan pada QS. al-Taghabun 14-15 ini, orang tidak langsung ditegur karena mencintai harta benda dan anak keturunan, namun Cuma diberi peringatan bahwa keduanya itu adalah merupakan sebuah cobaan. Maka kalau orang tidak lupa di sisi Allah adalah pahala yang besar, tidak akan sampai harta benda dan anak-anak itu akan menghalanginya di dalam menuju pahala yang disediakan oleh Allah, karena kalau amal ibadah tidak ada, harta itu memang bisa menjadi musuh besar, apalagi kalau harta itu didapat dari jalan yang tidak halal. Begitupun juga anak-anak itu jika mereka setelah dewasa, dan didikan agama tidak ada pada mereka, bisa saja mereka jadi musuh dan durhaka, karena berlainan pendirian dan berbeda pemilihan dan paling parah apabila melawan dan menentang.

Dari keterangan dalam kedua ayat ini, ayat 14 yang mengatakan bahwa istri dan anak-anak mungkin akan menjadi musuh, dan ayat 15 yang mengatakan bahwa harta dan anak-anak bisa membawa cobaan, bukanlah berarti mencegah orang ragu-ragu mengurus harta benda dan anak-anaknya, melainkan menyuruh untuk selalu berhatihati, karena sebab yang dituju dalam hidup ialah ridho dari Allah.

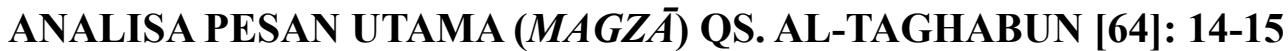

Dari data di atas bisa ditarik beberapa analisa mengenai pesan utama dari ayat tersebut, yang bertujuan dengan adanya ayat di atas, memperingatkan terhadap peran Suami untuk bisa bertanggung jawab atas keluarga dan harta yang dimiliki serta waspada terhadap keduanya, yaitu ketika menjadi seorang suami tetap harus wasapada dan berhati-hati dengan orang yang dekat dengan kita karena tidak menutup kemungkinan itu bisa menjadi penghalang bagi kita. Selain itu, ayat di atas juga mengajarkan kita untuk senantiasa bisa mengelola harta yang sudah kita miliki atas usaha yang dilakukan. Oleh sebab itu ada beberapa pesan utama yang bisa diambil dari ayat tersebut untuk diterapkan.

\section{Peringatan Istri dan Anak Bisa Menjadi Penghalang}

Ayat di atas menjelaskan terkait bahwa bisa saja istri dan anak bisa menjadi musuh dan menjadi penghalang untuk melakukan ketakwaan kepada Allah. Namun dalam ayat tersebut harus diperhatikan bahwa ayat tersebut merupakan sebuah peringatan, bukan sebuah bentuk anjuran. Peringatan tersebut bertujuan untuk teguran bahwa orang yang paling dekat dengan kita bisa saja menjadi musuh ataupun penghalang, maka oleh karena itu kita harus berhati-hati, tidak harus menjauhi dalam artian tidak menafkahi dan mengurusnya, namun berhati-hati dan selalu berwaspada, karena dalam ayat tersebut tidak menjelaskan kesemuanya istri dan anak itu adalah musuh, namun terkadang ada namun sedikit, karena banyak juga istri dan anak itu bisa membantu dan mensuport ke jalan yang benar.

\section{Larangan Melakukan Kekerasan Terhadap Istri dan Anak}

Pada ayat Q.S al-Taghabun [64]:14, dijelaskan bahwasanya istri dan anak itu menjadi musuh, sebagai penghalang untuk melaksanakan kewajiban sebagai seorang muslim.

\footnotetext{
${ }^{22}$ Ahmad Ibn Hanbal, Musnad ahmad ibn hanbal, (Kairo: Muassah qurtubah), Juz 5, h. 354.
} 
Diceritakan mengenai historis, bahwa suami mengetahui istrinya menjadi penghalang, seorang suami ingin melakukan tindakan kekerasan terhadap istri dan anaknya, namun upaya itu ditegur oleh Allah dengan menurunkan ayat lanjutanya yaitu dan jika kamu memaafkan dan santuni serta mengampuni (mereka) maka sesungguhnya Allah Maha Pengampun lagi Maha Penyayang. Meskipun telah mengetahui bahwa istri dan anak bisa saja menghalangi, namun sikap yang harus dilakukan adalah dengan berhati-hati dan waspada, tanpa menyakiti dengan tindakan kekerasan terhadap anak dan istri, harus bisa memafkan serta menyantuni dengan cara bijak.

\section{Mengelola Harta dan Mendidik Anak}

Pada dasarnya seseorang yang yang mempunyai harta banyak, pasti seseorang tersebut akan menjadi bangga dan senang, sebab segala keinginannya akan terpenuhi, dan juga seseorang tersebut apabila dikaruniai anak-anak atau keturunan juga pasti merasa senang karena diberi keturunan. Namun diantara keduanya harta dan anak-anak itu bisa juga menjadi sebuah fitnah (cobaan/ujian), sebab apabila tidak bisa mengelola harta dan juga mendidik anak, bisa saja keduanya melalaikan dari mengingat Allah (QS. al-Munafiqun ayat 19), karena keduanya bisa saja menyibukkan kedalam hal duniawi, hal ini juga dijelaskan dalam QS al-Kahfi (18) :46.

Mengingat pentingnya harta dalam kehidupan manusia, Al-Qur'an menamakan dengan istilah $m a t \bar{a}$ ' yang berati sumber kesenangan/kenikmatan (QS Ali Imran [3]:14), namun harta itu hanyalah merupakan sebuah perhiasan dunia (QS al-Kahfi [18]: 46), ayat tersebut menamai harta dan anak sebagai zinah, yaitu hiasan atau sesuatu yang dianggap baik dan indah, karena ada unsur keindahan pada harta disamping manfaatnya, demikian juga pada anak terdapat keindahan, disamping anak dapat membela dan membantu orangtuanya. Dijelaskan pada QS. al-Syu'ara [26]: 88, ketika suatu hari harta dan anak-anak tak berguna, yang mana ketika pada hari akhir nanti, manusia tidak bisa saling tolong menolong, termasuk harta dan anak juga tidak mampu memberikan perlindungan.

Maka dari sini bisa kita ambil maghza (pesan utama) pada ayat ini, bahwa kita harus bisa mengelola harta yang kita punya, jangan sampai dengan harta yang dimiliki bisa melalaikan ketakwaan dan ketaatan terhadap Allah, mengelola harta dengan cara bersedekah, menginfakkan sebagian harta kita, dengan nafkah yang baik, dan itu bisa kembali kebaikannya pada diri kita sendiri, penjelasan ini dijelaskan pada ayat setelah ini (munasabah) QS. at-Taghabun [64]:16. Seseorang selain harus bisa mengelola harta yang dimilik juga harus bisa mendidik anak-anak menjadi anak yang shalih dan berbakti kepada kedua orang tua, karena keduanya antara harta dan anak juga termasuk amanah yang harus bisa dijaga, mendidik anak tidak hanya sekedar menuruti apa yang dia mau, apabila menuruti semua keinginannya juga bisa mencelakakan kita sendiri dengan kedurhakaannya. Mengelola harta dan mendidik anak ini juga diajarkan Nabi, seperti pada yang diriwayatkan Abu Hurairah: Rasulullah SAW bersabda: jika sesorang meninggal dunia, maka terputuslah amalannya kecuali tiga perkara: shodaqah jariyah, ilmu yang bermanfaat, anak yang shaleh yang mendoakannya (HR. Muslim). ${ }^{23}$

\footnotetext{
${ }^{23}$ Muslim ibn al-Hujāj al-Naisābūrī, Șaḥịh Muslim, (Bairut: Dar Ihya'), Juz 3, h. 1631.
} 
Kewaspadaan terhadap Keluarga dan Harta dalam QS. Al-Taghabun [54]: 14-15

(Aplikasi Pendekatan Ma'nā-cum-Maghzā)

\section{PENUTUP}

Melalui Aplikasi pendekatan Ma'nā-cum-Maghzā, dapat dipahami bahwa QS AtTaghabun [64]: 14-15 memberikan pelajaran bahwa dalam berkeluarga sebagai seorang kepala keluarga harus mempunyai kewaspadaan terhadap bahaya anggota keluarga karena bisa ada kemungkinan menjadi musuh dan pengahalang bagi kita, maka dengan ayat ini diperingatkan dengan bahaya tersebut, maka untuk mengahadapi hal tersebut juga tidak dibenarkan apabila sampai melakukan tindakan kekerasan kepada istri dan anak, sifat yang kita ambil adalah dengan baik untuk menegurnya dan juga harus bisa memaafkan. Selain itu berkeluarga juga tidak lepas dari harta untuk memenuhi kebutuhan, namun dalam urusan harta kita harus bisa mengelola harta tersebut dengan baik, karena harta adalah merupakan sebuah cobaan.

\section{DAFTAR PUSTAKA}

Al-Bazzar, Abu bakar ahamd bin umar. Musnad Al-Bazzār, Madinah: Maktabah al-'ulūm wa al-Hukm, 2009.

Al-Halāwī, Abd al-`Azīz. Fatāwī wa aqdiyati amīr al-mu'minīn 'umar ibn al-Khatb, Kairo: maktabah Al-Qur'an.

Al-Suyūti, Jalāl al-dīn. Lubāb al-nuqūl fi asbāb al-nuzūl, Bairut: Mu'sasah al-kitab alsaqafiyah, 2002.

Al-Tabari, Jāmi' al-Bayān fì Ta'wīl al-Qur'ān, Bairut: Muasasah al-risalah, 2000.

Ansori, Muhammad gilang. "Peranan wanita sahabat Rasulullah SAW dalam perang uhud tahun 3H/625M", Skripsi fakultas Adab dan Humaniora UIN sunan ampel, Tahun 2018 .

Arifah, Erika Wijayanti. "Konsep Pendidikan Keluarga dalam Al-Qur'an Surat AlTaghabun Ayat 14-16," Skripsi-Sarjana IAIN Salatiga, 2018.

Artyasa, Usin. Ternyata balasan memberikan pinjaman lebih besar daripada sedekah, Bandung: ruang kata, 2013.

Fadilah, Adi. "Ma'na-cum-maghza sebagai pendekatan kontekstual dalam perkembangan wacana hermenutika Al-Qur'an di Indonesia," Jurnal Of Qur'an and Hadith studies, Vol 8, No 1, Januari-juni 2019.

Fathi, Adil. Ketika suami istri hidup bermasalah, Terj. Abd Hayyie, Jakarta: Gema insani, 2005.

Hamka, Tafsir al-Azhar, Singapura: pustaka nasional.

Hanbal, Ahmad Ibn. Musnad ahmad ibn hanbal, al-Qahirah: Muassah Qurtubah.

Ibn Manzur, Lisan al-Arab, bairut: Dar al-Kutub al-Alamiyyah, 2008.

Kathīr, Ibnu. Tafsīr Ibnu Kathīr, Terj. Abdul Ghofar Dkk, Bogor: pustaka imam al-syafi'i, 2004.

Nelli, Jumni. "Analisis tentang kewajiban nafkah keluarga dalam pemberlakuan harta bersama”, Jurnal Al-Istinbath: Jurnla Hukum Islam, Vol. 2, No. 1 (2017).

Syamsuddin, Sahiron. Hermeneutika dan Pengembangan Ulumul Qur'an, Yogyakarta: pesantren nawesea press, 2017. 